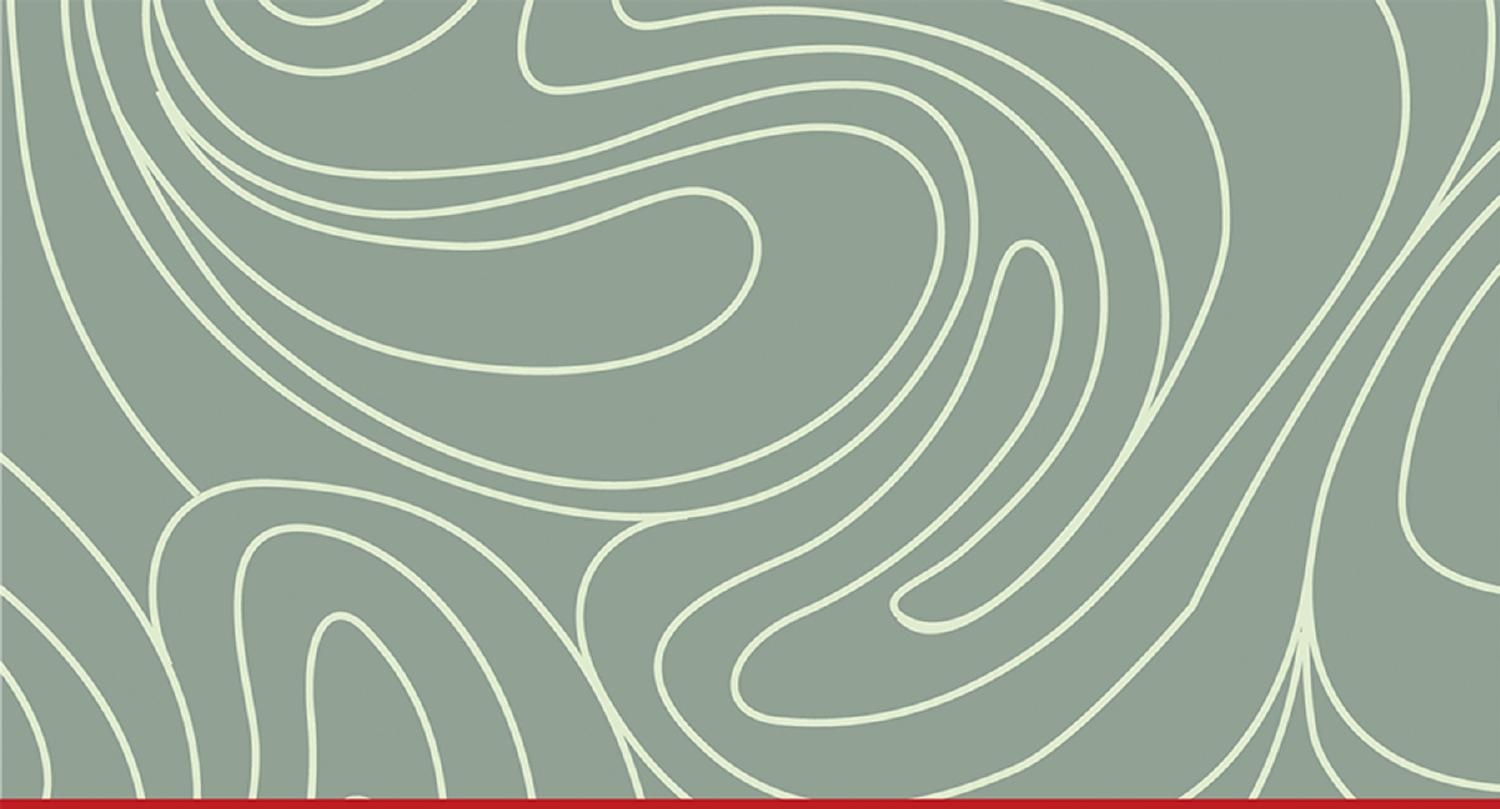

Routledge Studies in Nineteenth-Century Literature

INVENTING THE POPULAR

PRINTING, POLITICS, AND POETICS

Bettina Lerner

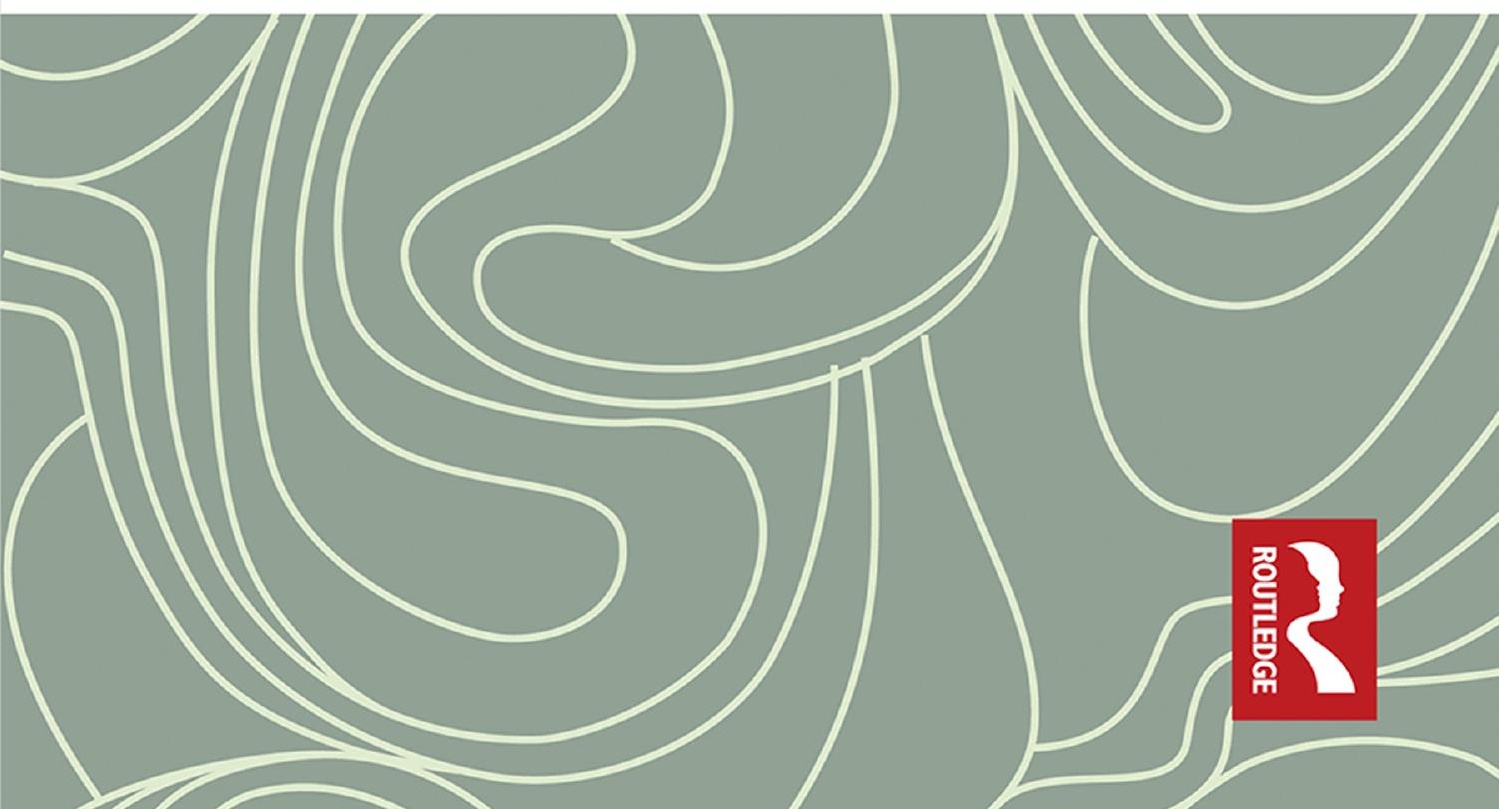




\section{Inventing the Popular}

Inventing the Popular: Printing, Politics, and Poetics explores texts written, published, and disseminated in France by a politically and socially active group of working-class writers during the first half of the nineteenth century. Through a network of exchanges featuring newspapers, poems, and prose fiction, these writers embraced a vision of popular culture that represented a clear departure from more traditional oral and printed forms of popular expression; at the same time, their writing strategically resisted nascent forms of mass culture, including the daily press and the serial novel. Coming into writing at a time when Romanticism had expanded beyond the borders of the lyric je, these poets explored various dimensions of connectivity and social relation finding interlocutors and supporters in the likes of Pierre-Jean de Béranger, Alphonse de Lamartine, George Sand, and Eugène Sue. The relationships they developed among themselves and the major figures of an increasingly socially oriented Romanticism were rich with emancipatory promise and reactionary temptation. Their writing constitutes an extensive archive of everyday life and utopian anticipation that reframes social Romanticism as a revelatory if problematic model of engaged writing.

Bettina Lerner is Assistant Professor of French in the Department of Classical and Modern Languages and Literatures at The City College, CUNY, USA. 


\section{Routledge Studies in Nineteenth-Century Literature}

For a full list of titles in this series, please visit www.routledge.com.

27 Three Traveling Women Writers

Cross-Cultural Perspectives of Brazil,

Patagonia, and the U.S., from the Nineteenth Century

Natália Fontes de Oliveira

28 For Better, For Worse

Marriage in Victorian Novels by Women

Edited by Carolyn Lambert and Marion Shaw

29 Questions of Authority

Italian and Australian Travel

Narratives of the Long Nineteenth Century

Laura Olcelli

30 Branding Oscar Wilde

Michael Patrick Gillespie

31 Hardy Deconstructing Hardy

A Derridean Reading of Thomas Hardy's Poetry

Nilüfer Özgür

32 Jane Austen's Geographies

Edited by Robert Clark

33 Vision and Character

Physiognomics and the English Realist Novel

Eike Kronshage

34 Melville and the Question of Meaning

David Faflik

35 Inventing the Popular

Printing, Politics, and Poetics

Bettina Lerner 


\section{Inventing the Popular Printing, Politics, and Poetics}

\section{Bettina Lerner}


First published 2018

by Routledge

2 Park Square, Milton Park, Abingdon, Oxon OX14 4RN

and by Routledge

711 Third Avenue, New York, NY 10017

Routledge is an imprint of the Taylor \& Francis Group, an informa business

(C) 2018 Taylor \& Francis

The right of Bettina Lerner to be identified as author of this work has been asserted by her in accordance with sections 77 and 78 of the Copyright, Designs and Patents Act 1988.

All rights reserved. No part of this book may be reprinted or reproduced or utilised in any form or by any electronic, mechanical, or other means, now known or hereafter invented, including photocopying and recording, or in any information storage or retrieval system, without permission in writing from the publishers.

Trademark notice: Product or corporate names may be trademarks or registered trademarks, and are used only for identification and explanation without intent to infringe.

Library of Congress Cataloging-in-Publication Data

A catalog record for this book has been requested.

ISBN: 978-1-4094-3676-8 (hbk)

ISBN: 978-1-315-58971-8 (ebk)

Typeset in Sabon

by codeMantra 
To Lía Schwartz

In memory of Isaías Lerner 


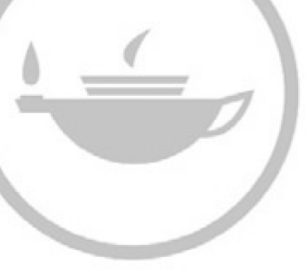

Taylor \& Francis Taylor \& Francis Group

http://taylorandfrancis.com 


\section{Contents}

Preface: Beyond popular culture ix

1 The mysteries of writing 1

2 The worker press, 1830-48 33

3 Béranger's step-children: Social poetry in Jules Vinçard, Savinien Lapointe, and Charles Poncy 59

4 The ideal companion: Friendship and fraternity in George Sand and Agricol Perdiguier 96

5 The poet and the seamstress, or on the destiny of poetry 130

Epilogue: After the Fall 165

Selected bibliography $\quad 171$

Index 183 


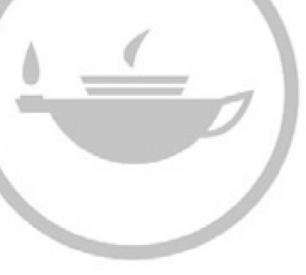

Taylor \& Francis Taylor \& Francis Group

http://taylorandfrancis.com 


\section{Preface}

\section{Beyond popular culture}

J'aime la poésie populaire avec ses rimes en gros sabots et ses sentiments naturels.

—Champfleury, Le réalisme

Charles Poncy, a twenty-three-year-old bricklayer and poet from the port city of Toulon, arrived in Paris around two o'clock in the afternoon on November 1, 1845. Just a few years earlier, he had been invited to read one of his own poems at a meeting of his local Academy of Science and Literature and quickly became something of a literary celebrity in his hometown. With help from a few members of this academy, he published his Marines (1842) and his fame spread beyond Provence, winning him praise from George Sand and an invitation to visit the nation's capital. On that fall afternoon, Poncy was met at the barrière de la Gare by a large delegation of worker-poets, including the ruler-maker, songwriter, and journalist Jules Vinçard and the shoemaker and journalist Savinien Lapointe, who had raised money to bring Poncy to Paris, and who accompanied him to a banquet they had organized in his honor. This literary happening seems to have been a rousing success, but a few days later, a brief and scathing account of the dinner appeared in the pages of the satirical periodical Le Corsaire-Satan, mocking the carnivalesque reversal of cultural orders that the term worker-poet implied: "If we're willing to stop at fairground stands to see five-legged goats and two-headed children," the critic ironized, "why not take the trouble to enjoy the curious object [curiosité] known as a worker-poet?" Penned by Champfleury, the review derided the workers' literary pretensions, equating the material paucity of the celebratory banquet with the cultural poverty of Poncy's writing. "Take it as an axiom," he quips, "make sure you've had a good dinner before attending a popular banquet." Workers could not properly aspire to be poets, his argument went, and the mere thought of this dual identity produced a phantasmatically queer set of associations that he gleefully enumerated: "worker-poets are amphibious beings, anomalies, hermaphrodites;" they were sideshow freaks and objects of his withering disdain. ${ }^{1}$ 
The targets of Champfleury's satire wasted no time in striking back, taking to the pages of L'Union, a monthly newspaper published by and for workers, to retaliate against the "insolent pasquils from the puppets of the press." Written by watchmaker Charles Gaumont, this carefully worded response decodes Champfleury's rhetoric and turns it back against him, pointing out the awkward turns of phrases and convoluted style that make him an "acrobat-critic" rather than a serious writer, and far more of a circus clown than the worker-poets he had tried to relegate to the county fair. Against Champfleury's bid to exclude workers from the "culture of letters," they reclaim dignity for those who "by dint of their intellectual labor and devotion have conquered the right to represent the nation of workers in its most elevated and poetic personification." 2 This dustup in one of the corners of the petite presse highlights some of the debates over popular culture that took place in France in the years leading up to the Revolution of 1848. Tense and highly mediatized exchanges like these showcased worker-poets' investment in material and literary questions alike and their strategic mobilization of irony in the struggle to exercise control over consumers and producers of a vaguely defined culture populaire. I argue here that worker-poets, their supporters, and their critics waged a veritable culture war to ambivalent ends. Indeed, something of Champfleury's description of worker-poets as monstrous beings still echoes more than a century later in Michel Ragon's assertion that there is something "incongruous" about the kind of proletarian literature whose history he tries to trace and whose value he sets out to defend. ${ }^{3}$

This book explores texts written, published, and disseminated by a politically and socially active group of French working-class writers during the first half of the nineteenth century. Through a network of exchanges featuring newspapers, poems, and prose fiction, these writers embraced a vision of popular culture that represented a clear departure from more traditional oral and printed forms of popular expression; at the same time, their writing strategically resisted nascent forms of mass culture, including the daily press and the serial novel. Coming into writing at a time when Romanticism had expanded beyond the borders of the lyric je, these poets explored various forms of connectivity and social relation, finding interlocutors and supporters in the likes of Sand but also Pierre-Jean de Béranger, Victor Hugo, and Alphonse de Lamartine. The relationships they developed among themselves and the major figures of an increasingly socially oriented Romanticism were as rich with emancipatory promise as well as with reactionary temptation. The written traces that remain are not incongruous in the sense that Ragon implies, but rather constitute an extensive archive of everyday life and utopian anticipation that can help us rethink social Romanticism as a revelatory if problematic model of engaged writing.

Pierre Bourdieu may have been largely right to point out that scholarly approaches to popular culture tend to operate between twin "poles 
of devaluation and rehabilitation." ${ }^{4}$ The questions I ask in this book, however, try to look beyond this polarization. I am far less invested in restoring prominence or conferring added value to this largely overlooked corpus than I am in exploring the freedoms and constraints that structured experience for those writers and readers who were active on the margins of cultural production in the 1830s and 1840s. In this, my approach resonates with what Stephen Best and Sharon Marcus have described as surface reading, a way of reading that questions the assumption that what is most interesting or relevant about a particular text is necessarily its hidden or latent meaning. ${ }^{5}$ The texts I examine do not so much repress their own history as lay bare a set of exchanges that have traditionally been omitted from literary-historical accounts. Rather than read them as somehow representative of the working-class movement or alongside assumptions about what constitutes popular culture, I try here to reassemble the network of multitudinous and contradictory affiliations and repudiations their writers professed. Brought together less by the working-class backgrounds, they had in common than by their shared commitment to transforming literature from the bottom up, their exchanges were boisterous and insistent; they were not shy about engaging with literary celebrities and the mass press, and they often succeeded in getting their attention, thereby impacting the way in which social Romanticism developed as a movement. Yet when reading their public and private correspondence today, it is all too easy to dismiss social romantics like Lamartine, Sand, and Sue as moralizing, paternalistic, and patronizing (which they often were) and, conversely, to read workers' goals as purely utopian or phantasmatic. Ultimately, however, this kind of reading risks missing the emancipatory drive and intertextual richness that fueled the emergence of what I am calling an alternative public sphere that working-class journalists and poets created in the mid-nineteenth century. The pages that follow amplify the traces that remain of this sphere by exploring its extant texts on their own terms and searching for how they relied on one another to produce new and lasting meaning.

More than anything else, this book is about encounters, some real and some fictionalized, that informed how a group of writers tried to position themselves in a rapidly changing literary field. My own encounter with works by these poets first came (as it has for many) through the work of Jacques Rancière, who brought renewed critical attention to this corpus of texts in the 1980s. Perhaps his most valuable insight was to read this poetry outside of and beyond a Marxist framework of a coming to class consciousness. As he writes, "Workers' poetry is not a means to revindication; it is an end unto itself, the representation of the self as Other." Writing as a worker was not easy, and some, such as Hégésippe Moreau and Adolphe Boyer, paid a heavy price for their attempts to defy the constraints imposed on them as manual laborers 
and to claim freedom and equality as artists instead. While Rancière has written extensively on the meaning and consequences of these workers' attempts to redraw the boundaries of the sensible, my focus here is on the expressive communities that emerged from their transgression of the boundaries between labor and literature, and the relations they created in and through writing. Their results were not always harmonious, of course. At times, the sphere they created threatened to collapse into the universalizing impulses that reproduced key exclusions and elisions. It nonetheless remains a powerful example of a collective attempt to enact aesthetic and political change.

This book took much longer to write than I could have expected it to, and my having been able to complete it owes much to the patience and generosity of a number of individuals and institutions. I carried out much of the initial research thanks to an ACLS fellowship, and some of the first drafts were written in the Wertheimer Study at the New York Public Library. These drafts were immeasurably improved with helpful guidance from friends and colleagues at CUNY, both in City College's Department of Classical and Modern Languages and Literatures and at the Graduate Center's PhD Programs in Comparative Literature and in French. I owe a special debt of gratitude to Andrea Goulet, Lawrence Kritzman, and Maurie Samuels for supporting this project and providing invaluable feedback on it when it was still very much unformed. I also want to thank David Bell, Nelly Furman, and Catherine Nesci for their support along the way. I was lucky to have regular meetings in New York with Rachel Corkle, Natasha Lee, Rachel Mesch, Raisa Rexer, and Chapman Wing, who pushed me to set deadlines, share drafts, and finalize the manuscript. Patrick Bray and Kathryn Lachman provided keen insights and editorial suggestions; my argument is clearer thanks to them. My deepest gratitude goes to Paul Haacke for sharing in the journey.

\section{Notes}

1 Baillet states that the banquet for Poncy was called off by the police, but I found no evidence to support this claim in the worker press. See De quelques ouvriers-poètes, 104. Champfleury's article "Les ouvriers poètes," appeared in Le Corsaire-Satan, November 11, 1845, 1-2. All translations are mine unless otherwise indicated.

2 L'Union, November-December, 1845.

3 Ragon, Histoire de la littérature prolétarienne, 9.

4 Bourdieu, "La sociologie de la culture populaire," 119. Quoted in Rigby, Popular Culture in Modern France, 118.

5 As Best and Marcus explain in their introduction to a special volume of Representations, this way of reading both draws from and also imagines alternatives to the kind of symptomatic reading popularized by Fredric Jameson's seminal work, The Political Unconscious; see "Surface Reading: An Introduction," 1-21.

6 Rancière, "Ronds de fumée," 36. 


\section{The mysteries of writing}

Ôtez les livres médiocres, et l'on ne saura bientôt plus lire ni distinguer les bons.

Part eight of Eugène Sue's best-selling serial novel Les Mystères de Paris (1842) takes readers behind the thick walls of a Parisian prison - this time, to solve the "mysteries" of readerly taste and writerly talent among some of nineteenth-century France's most marginalized individuals. In this scene, a group of condemned thieves and murderers have gathered to hear the talented raconteur known as Pique-Vinaigre tell the story of "Gringalet et Coupe-en-Deux." In tones meant to recall a traditional fireside veillée, the storyteller holds his audience captive with the travails of the eponymous young hero who is tortured and nearly killed by his sadistic guardian Coupe-en-Deux before he is ultimately saved in the most improbable and gruesome of ways, when an enraged ape turns on the villain, slashing his throat with a razor. Pique-Vinaigre's story clearly draws on the mixed repertory of early nineteenth-century popular culture ${ }^{1}$ : its cast of characters hails from the carnivalesque world of street performers; its violent sensationalism evokes the kinds of crimes recounted in cheaply printed canards; finally, like most melodrama, the story stages an ultimate return to order and rewards Gringalet for his virtue. Moreover, Pique-Vinaigre's tale is not just entertaining; it also successfully thwarts a murder plot. By awakening a latent sense of justice and solidarity in this gang of hardened criminals, the story ultimately dissuades them from killing a fellow inmate. As such, the episode functions as a mise en abyme of Sue's own moralizing novelistic project, which he describes as "a bad book, from the artistic point of view," but "one which, we maintain, is not bad at all from the moral point of view." "

Pique-Vinaigre's success as a storyteller is meant to refract the phenomenon that Sue's novel had become since its first installment appeared in the Journal des débats on June 19, 1842; over the course of its triumphant sixteen-month run, it entered collective consciousness in unprecedented ways in part by facilitating "the social identification of 


\section{The mysteries of writing}

couches populaires with the working classes," while also "calling attention to their partial cultural enfranchisement as nouveaux lecteurs." 3 That Sue's novel attracted a considerable number of working-class readers is well known; what is less often stressed is that some of these readers were writers as well, a phenomenon to which the figure of Pique-Vinaigre alludes, albeit in oblique and distorted ways, when he promises to commit his story to paper for his nieces and nephews: "I will write it for your children," he tells his sister, "Gringalet et Coupe-en-deux will entertain them." Pique-Vinaigre's promise might just as easily have been read as a threat by critics wary of a seeming explosion of working-class writers who had begun to publish essays, fiction, and poetry, both in newspapers they themselves produced as well as in bound volumes, thanks in part to the support of social Romantics including Sue himself.

In this book, I explore texts produced and disseminated by a politically and socially active group of working-class writers who entered the literary field at the height of social Romanticism, inflecting the movement's trajectory and broadening its popular reach in the years leading up to and immediately following the Revolution of 1848 . Rather than read them as the by-product of social utopias like Saint-Simonism, or as appendices to works by better-known writers like Sue, Victor Hugo, Alphonse de Lamartine, and George Sand, I argue that this sizeable corpus of texts, created over more than a decade of concerted effort and interpersonal exchange, constituted a scene of significant cultural relevance and resistance in its own right. This hybrid mix of newspapers, poems, prose fiction, and essays had little in common with predominantly oral popular traditions of the kind that Sue nostalgically evokes and mourns through the figure of Pique-Vinaigre. Instead, these writers openly sought to position themselves within the rapidly changing literary field by publicly engaging with its principal mediatic forms including the press and the serial novel. For Jacques Rancière, who brought renewed critical attention to this archive in the 1980 s, these writers came to occupy precarious positions in their drive to transgress boundaries between aesthetic and politics, and labor and literature. ${ }^{5}$ In the process, I argue here, they produced new meanings out of existing discourses and navigated significant practical and theoretical impasses as they tried to construct a community of readers with shared political, social, and cultural goals.

The texts I examine here were thus part of a moment of cultural flux that Sue's novel carefully tried to contain behind heavy prison walls or push to the margins of its narrative. ${ }^{6}$ Nonetheless, it is precisely at the outer edges of dominant cultural production that interference from these alternative voices and approaches can make themselves heard. One particularly salient example can be found in the actual margins of literary history in the form of a letter that accompanied the very last installment of Les Mystères de Paris in the October 15, 1843, issue of Le Journal des débats. Sue concludes his novel by writing a letter to 
the newspaper's editor, in which he praises a modest publication put together by "a few honest and enlightened artisans," who expressed their views on labor reform in acceptably moderate terms. Created by Saint-Simonian workers in 1839, La Ruche populaire had recently come under new leadership and was beginning to move in a new direction that held obvious appeal for the best-selling novelist. The October 1843 issue, from which Sue quotes at length in his letter, includes a quote from the novel's protagonist Rodolphe (reprinted on the masthead in subsequent issues): "Helping those who voice their grievances is a good thing $[\ldots]$ preventing poverty and the temptations that lead to crime is even better." The newspaper, while claiming to represent the interests of the working classes, had positioned itself as a vehicle for Sue's sociallyconscious Romanticism and its moralizing philanthropy.

For the editors at the rival working-class paper L'Atelier, this quid pro $q u o$ was as blatant as it was intolerable: La Ruche populaire gave Sue further access to working-class readers and lent him an aura of authenticity, while the paper's new editor, the printer François Duquesne, could capitalize on the famous novelist's patronage to sell more copies of his paper. L'Atelier, some of whose founding members had briefly worked on La Ruche populaire when it was first founded in 1839, was ruthless in calling out a competing publication for what they saw as a shameless and mendacious publicity stunt amounting to a fawning apology for Sue's novel. ${ }^{7}$ Even before Marx and Engel's comments on Szeliga's review of Les Mystères de Paris appeared in their attack on the group of young Hegelians in The Holy Family (1845), the Parisian newspaper L'Atelier had already taken Sue's novel to task in markedly similar terms. The November 1843 issue of the artisan-owned and written newspaper denounced the novel for its "philanthropic mystification," warning readers not to buy into the "false pretense of Christian charity permeating this so-called humanitarian novel." In their view, Sue's depiction of the lower classes didn't so much lack veracity as honesty. Sue was less interested in social change than in entertaining his readers. Because of this, the scenes of poverty and misery that he painted fell flat and felt false. However, "If the author had bothered to visit our industrial cities, or even just the outer edges of Paris's faubourgs, he would have seen that reality is at least as bad as the suffering his novel only imagines." ${ }^{8}$ L'Atelier argued that the time had come to replace the novel's fantastical modes of representation with the kind of in-depth reporting and cultural critique that they themselves had been publishing since 1839 .

L'Atelier and La Ruche populaire thus represent two vocal poles in the working-class reaction to Sue's rise as a best-selling author. Still others, like the shoemaker and poet Savinien Lapointe, took a more nuanced approach. His two-hundred-line ode, "De mon échoppe à M. Eugène Sue" appeared in the inaugural issue of L'Union, another working-class newspaper created that same year by former members of La Ruche populaire 


\section{The mysteries of writing}

who were dissatisfied with the direction it had taken under Duquesne's directorship. On the surface, Lapointe's ode is true to its genre, delivering high praise for the novel and its author. Nonetheless, from its opening stanza, Lapointe's lyric voice calls attention to itself just as much as to the famous author he purports to lionize, using the novel as a pretext for shedding light on his own experiences as a poet who, born into the working classes, feels excluded from the world of literature: "Those yapping basset hounds bit me/Telling me, in bloated haughty terms, /That smocks weren't allowed in the world of art." In spite of his critics, whom he depicts here as guard dogs bent on keeping the worker-poet from entering the literary sphere, he nonetheless perseveres: "Besides, I sing out in the open, /Whoever wants to can hear me on my iron branch." 9 Lapointe is pointedly less invested in the fictionalized portrait Sue paints of the lower classes than he is in the room he hopes the novel has made for writers from these classes like himself to intervene in a newly inclusive literary field. His particular take on the well-worn metaphor of the poet as bird is particularly telling in this regard. His personal resilience and the strength of his words are evoked by the branch of steel on which he sits, but it is the reference to singing "out in the open" [en plein air] that stands out as especially significant. Lapointe had indeed claimed a public persona as a poet, since his poems, articles and later on, his stories, circulated in working-class newspapers and in book-length collections like the Poésies sociales des ouvriers (1841) and his own Une Voix d'en bas (1844). While the panorama of popular culture that Les Mystères de Paris exploits through characters like Pique-Vinaigre is consistently situated underground and behind jail walls, a very different kind of popular expression thrived in the 1840s, albeit precariously, as newly resonant voices made themselves heard in the public sphere.

Working-class newspapers (including L'Atelier, La Ruche populaire, and L'Union) and the voices of working-class writers whom they helped to promote (like Lapointe) contributed throughout the second half of the July Monarchy to a popular movement whose cultural forms were entirely distinct from the oral folktales, age-old chapbooks, sensational broadsides, and salacious songs that academics like Charles Nisard would come to both privilege and police in the 1850s and 1860s as the mythological origins of a culture populaire nationale. ${ }^{10}$ Some of the writers from the lower classes whose works I explore in this book conceptualized their approach to journalism and literature in ways that connected with social Romantics like Hugo, Lamartine, Sand, and Sue himself, with whom some of these self-described worker-poets corresponded and collaborated. Others within this same generation of working-class writers were more skeptical and critical of social Romanticism, seeking to position their works against the kinds of moralizing melodramas and best-selling serial novels that made up a significant part of France's literary production in the first half of the nineteenth century. Read alongside 
one another, these texts lay out the aesthetic, social, and political tensions that shaped emerging critical approaches to high and low culture.

My primary aim here is to show how these writers created alternative systems of literary and journalistic discourse and debate that openly contested the structure and limits of the dominant bourgeois public sphere that had emerged in France in the late eighteenth century and continued to grow. I approach these texts in terms of what critical theorists Oskar Negt and Alexander Kluge as well as feminist scholars like Nancy Fraser and Lauren Berlant have identified as variants of this dominant bourgeois public sphere. I will return to the theoretical stakes at work in the conceptualization of these alternative spaces as proletarian public spheres, subaltern counterpublics, or intimate publics in more detail below, but I want to note for now that this generation of working-class writers and their readers created a space of popular production that was at its most active during the second half of the July Monarchy and fed into the revolutionary fervor leading to the Revolution of 1848 before ultimately receding during the Second Empire. One of the principal goals of this book, then, is to examine the traces of a sphere whose contours have been blurred but whose discourses reveal much about Romanticism's waning years. In particular, this alternative sphere drew on and reorganized socialist utopian discourses and narrative modes, most notably sentimentality as (oftentimes problematic) frameworks in their attempt to resist and rewrite the relations of production that increasingly defined juste milieu society.

These particular discourses were not invented by the authors whose poems, articles, and fiction are the subject of my inquiry. Many of them appropriated and transformed emergent socialist theories and sentimental literary tropes commonly associated with established thinkers and writers of the late Romantic period. To the extent that literary scholars remember and study figures like Charles Poncy, Agricol Perdiguier, and Reine Garde, it is often in the context of their correspondence with now-canonical figures like Sand and Lamartine. The novels I study in later chapters, including Sand's Le Compagnon du tour de France (1840) and Lamartine's Geneviève (1851), turn out fictionalized portraits of some of the same workers with whom they corresponded and whose writing they supported, but do so in ways that ultimately neutralize their radical positions in order to instead promote images of socially and politically submissive artisans akin to the noble savages of exotic lore. Novels such as these necessarily complicate the relationship between working-class writers and the more established authors whose literary mentorship they sought out. Nonetheless, I argue that these workers' relationships with writers like Lamartine, Sand, and Sue cannot be understood in terms of one-sided literary patronage alone. More precisely, labeling these relationships in terms of paternalism or influence risks obscuring far more complex questions of class, gender, and genre that structured popular 


\section{The mysteries of writing}

cultural production at this time. Many working-class writers turned to social Romanticism because it offered a readily accessible vocabulary through which to resist extant social and economic forms. Their appropriation was just as strategic as it was convenient, for it showcased a critique of social Romanticism's philosophical and aesthetic principles from within. While literary historical accounts of social Romanticism routinely highlight its investment in a mythological portrayal of the lower classes, they also tend to gloss over the ways in which these classes read and responded to literature that claimed to represent them and speak in their name. ${ }^{11}$ I argue that their complex and creative engagement with the social question was part of a vibrant and politically charged alternative public sphere that underpinned the populaire of the time.

\section{Paris in print: La masse lisante}

The popular cultures of reading and writing that I examine in this book were rooted in the everyday lives of artisans, both men and women, most (but far from all) of whom were based in France's capital. ${ }^{12}$ Over the course of the half of the nineteenth century, Paris grew to be nearly two times its size in population, bringing a sizeable labor force to a city that numbered more than one million inhabitants by 1848 . In the words of typesetter and journalist Anthîme Corbon, Paris of the 1830s and 1840 s was the nation's "central workshop" drawing workers from all over the country. ${ }^{13}$ By mid-century, $15 \%$ of all French workers lived in the capital, and nearly one out of every two Parisians identified as ouvriers. ${ }^{14}$ This heterogeneous labor force, comprised of both skilled and semiskilled labor alike, was excluded from the political process but was nonetheless brought together by a strong tradition of political protest, radicalism, and revolution that went along with relatively high levels of literacy. ${ }^{15}$

For much of the century, Paris was dominated by small-scale industry employing skilled artisans who produced furniture, jewelry, tapestries, and other luxury consumer goods for which the capital became known. ${ }^{16}$ Alongside these skilled artisans, the capital also drew semiskilled and menial laborers from rural areas to its workforce. In this diverse setting, the identifier ouvrier was employed almost interchangeably alongside its correlates artisan, travailleur, producteur, and prolétaire. The differences between these individual terms were often blurred, such that the editors of a working-class newspaper like La Ruche populaire could claim to address "the class of plebeians, proletarians, workers, since they make up a class." 17 The perpetual uncertainty of artisans' social and economic status helps explain the concerted effort that the writers I study here made to organize themselves and their readers into a politically effective social body. At the same time, however, the instabilities and ambiguities that characterized their everyday lives made for complex 
modes of identification and self-expression. This relatively small and apparently homogeneous group of writers with overlapping goals nevertheless gave rise to a heterogeneous body of writing that cannot be read as the expression of a unified, working-class experience not least because working-class experience was itself so varied and unpredictable.

An artisan - sometimes even a skilled artisan - could not always count on learning and exercising a single trade throughout his entire life, as a number of firsthand accounts of the period clearly show. For instance, employed at a young age by a wool carder who fell on hard times, Norbert Truquin spent his adolescence teetering on the edge of unemployment and destitution only to survive through a series of short-term menial jobs, including errand boy for a pair of aging prostitutes, machine tender in a spinning mill, wandering salesman, metalworker, and canal digger, before becoming a silk weaver and subsequently leaving France altogether for Algeria and then Latin America. ${ }^{18} \mathrm{~A}$ similar fate befell Louis-Marie Ponty, who worked as a blacksmith in Paris before turning to rag-picking and cesspool-cleaning to support his talent for poetry and songwriting. ${ }^{19}$ Indeed, as Rancière argues against historians like Sewell, the workplace did not necessarily provide the only, nor indeed the most important, framework in the everyday lives and utopian aspirations of France's nineteenth-century artisans. ${ }^{20}$ The shared horizon of experience that shapes texts by Ponty, Truquin, and others I examine here is less rooted in workshop routines than the conflict between the instability of the social identity assigned to them as workers and their individual commitment to reading, writing, and the dissemination of print.

Paris was also the heart of France's print industries. Paul Chauvet calculates that by 1818 , over three thousand typesetters, compositors, and press operators were employed in privately owned printshops located on the capital's Rive Gauche or for the monarchy's Imprimerie Nationale. ${ }^{21}$ The artisans who ran these printshops were broadly perceived as belonging to the elite rungs of the working class: among the best-paid ${ }^{22}$ and most universally literate of the artisanal work force, they laid claim to an ambiguous, even déclassé, social status:

He is a worker because he earns a salary and works for a master; he belongs to the people [peuple] by birth, by his alliances, his ways of life; however, his education and participation in the work of the mind bring him closer to the upper classes. ${ }^{23}$

From the perspective of the police, printshops were dangerous hotbeds of revolutionary activity. The Statistique des ouvriers de Paris an $1^{\text {er }}$ mars 1807 warned that "No other workers are more insubordinate, disposed to disorder and to coalition," than printshop workers. It is thus perhaps unsurprising that the first examples of the kind of print culture that I explore here first emerged in the weeks following the July Revolution 


\section{The mysteries of writing}

when different groups of printshop workers in Paris (as well as in Lyon) decided to write, edit, and distribute newspapers aimed specifically at a working-class readership. ${ }^{24}$

This first generation of working-class newspapers was born in the crucible of a Revolution famously instigated by the Bourbon monarchy's attempt to muzzle an increasingly rebellious press. When its five repressive ordinances appeared in the July 26 issue of Le Moniteur - the first of which suspended the liberty of the press - one group of workers in particular had special cause to feel threatened, not just politically, but economically as well. Fearing for their rights as well as their livelihoods, five thousand printers roamed the streets of the capital on July 27, 1830; eyewitness accounts from the time repeatedly remarked on the role printshop workers and journalists alike played in calling for defiance of Polignac's ministry. ${ }^{25} \mathrm{~A}$ few weeks after their victory on the barricades, several groups of workers in the printing industries in both Paris and Lyon tried to double down on their political triumph to foment a social and cultural revolution. Taking advantage of the new regime's short-lived liberalization of press laws, they created newspapers pitched directly to "workers from all the professions." 26 This first wave of working-class print died out a few months into the Orleanist regime, yet in spite of the passage of the September Laws of 1835 that reimposed draconian restrictions on the press, a second generation of Parisian workers' newspapers including La Ruche populaire and L'Atelier nonetheless followed after 1839 by avoiding overt political coverage to skirt the steep caution money most dailies had to pay. While the first workers' newspapers were created and run almost entirely by members of the printing industries, this second generation brought collaborators together from a variety of skilled trades, from printers and tailors, to woodworkers and shoemakers, who strove to rally the working classes around a common agenda of political and social emancipation. ${ }^{27}$

In fact, as Jeremy Popkin has argued, workers' newspapers during this period emerged as crucial sites for the construction and dissemination of social identities, in particular where workers were concerned. These papers established a metonymic relationship with the imagined community of workers whose political grievances they publicized, presenting themselves as an extension of the voices they sought to represent. ${ }^{28} \mathrm{At}$ the same time, they also actively tried to shape this community in ways advertised on their very mastheads: titles like Le Peuple and L'Artisan, or later, L'Union and L'Atelier, point to the drive to transcend existing divisions between trades by appealing to a broad coalition of workers as a socially distinct and unified social group. From the outset, the editors recognized that the realization of this ideal depended at least in part on the construction and diffusion of a shared culture among their target readership. Moreover, these newspapers sought to provide readers with the kind of cultural capital that might render their voices intelligible in 
the public sphere. To this end, they modeled reasoned debate in their columns and dedicated several pages in each issue to social commentary and often polemical book reviews. They engaged repeatedly and pointedly with the dominant daily press by discussing and carefully deconstructing articles about a number of topics relating to working-class life and experience. These newspapers thus purported to offer working-class readers an opening into a cultural realm normally out of their reach.

At the same time, they also compromised their pursuit of openness through sometimes didactic and prescriptive efforts to produce a uniform cohort of readers. The editors of most of these newspapers were forthright in their call to educate what they often described as the culturally underserved lower classes. Their carefully curated reading lists and acerbic attacks on cabarets and popular songs arguably reproduced, at least in part, those policing strategies visited on the lower classes by the State. For Richard Terdiman, the counter-discourse that opposition newspapers embraced may ultimately only have served to buttress the stable, hegemonic discourse of the very same mass press they sought to critique. ${ }^{29}$ There is some truth to this, for the plurality of radically independent voices and positions that the worker press highlighted in its pages threatened at all times to dissolve into the culture of the lettered elite that these papers mimicked. However, unlike Terdiman, I maintain that these working-class newspapers also constructed a productive discursive space within which material realities and utopian ideals were placed into sustained dialectical relation enabling both aesthetic innovation and sociopolitical contestation. Even as these newspapers may have reinforced certain aspects of dominant ideology, they nonetheless also supported practices that actively resisted the capitalist thrust of juste milieu society and fed into the revolution of 1848 . This is especially the case when it comes to the poetic voices that emerged from in between the disjoined columns of print.

After 1840, many of these writers, including Lapointe and Poncy, self-identified as poètes ouvriers and formed a veritable poetic movement that sent ripples through the cultural establishment. To be sure, a small but memorable handful of writers hailing from the artisanal classes had attained legendary status in the past, and at least one of them - seventeenth-century woodworker and poet from Nevers, Adam Billaut, known as Maître Adam or the "Virgil of the hand plane" - enjoyed a brief rediscovery at the turn of the nineteenth century thanks to the republication of a few of his poems and an eponymous vaudeville that premiered in $1805 .{ }^{30} \mathrm{~A}$ figure like Billaut, however, stood out in literary history as exceptional, all but confirming the rule that excluded working classes from artistic achievement. In contrast, the group of poets who came to the fore in the second half of the July Monarchy were perceived, albeit with a certain amount of hostility, as belonging to a full-blown movement. Newspapers like $L a$ Ruche populaire, L'Union, and La Fraternité de 1845 consecrated them 


\section{0}

as poètes ouvriers at the same time as middle-class readers learned about them in essays like Émile Souvestre's "Les penseurs inconnus," which appeared in the March 1838 issue of La Revue de Paris, and George Sand's "Dialogue familier sur la poésie des prolétaires," published in two parts in the Revue Indépendante of $1842 .{ }^{31}$

Sand and Souvestre hailed proletarian poets and thinkers as the coming of a newly democratic era, but for many critics at the time, the very term poète ouvrier was anathema to literature itself. Writing in $\mathrm{La}$ Revue des deux mondes, Eugène Lerminier assailed social Romantics and socialist utopians, whom he accused of preying on the credulity of poor artisans and luring them into a life of penury and crushed poetic dreams: "You arouse the most irritable of vanities in their hearts - the poet's vanity; souls that were once simple and quiet are now filled with agitation and the plotting of artificial sentiments." ${ }^{32}$ For Lerminier, the worker-poets were not artistic revolutionaries but merely symptoms of a dangerously contagious social philosophy which he associated primarily with Étienne Cabet's brand of communism along with other socialist utopias. His denunciations are marked by the kind of passion typical of a newly deradicalized former convert: trained as a lawyer, Lerminier himself had in fact once belonged to Paris's Saint-Simonian family and had collaborated with Pierre Leroux on the group's mouthpiece Le Globe. ${ }^{33}$ While his own socialist zeal had clearly waned by 1842 , many of the working-class writers he attacked still maintained strong attachments to socialist utopian movements of various kinds.

\section{Poetry and social utopias}

In 1831, a thirty-five-year-old ruler-maker named Jules Vinçard was carving out a meager living selling measurement tools to artisans and merchants in Paris. While making a round of deliveries, he noticed a poster pinned to the walls of the capital's Palais de Justice advertising a meeting for adherents of the Religion saint-simonienne: "These words in large print caught everyone's eyes," he recalled in the Mémoires he published toward the end of his life. Deeply skeptical of this newfangled religion (and even suspecting a Jesuit plot), he nonetheless agreed to accompany an enthusiastic young friend to a meeting. ${ }^{34}$ Vinçard's wariness soon waned, and he spent the next few years living with and writing songs for the Saint-Simonians in Paris, becoming deeply committed to the movement's ideals of unity and equality and to some of its former leaders for much of the rest of his life. Not all of the artisans who came into contact with SaintSimonian, Cabetist or other socialist theories that gained popularity during the July Monarchy became lifelong activists for their causes, but Vinçard's story speaks to the very real investment that some artisans made in social movements known primarily for the bourgeois journalists and intellectuals who led them. 
If July 1830 really did constitute "the cultural revolution of the century," as Philippe Régnier claims, Saint-Simonism arguably embodied the period's most liberatory ideals. ${ }^{35}$ After his death in 1825, Henri de Saint-Simon's disciples including Olinde Rodrigues, Saint-Amand Bazard, and above all Prosper Enfantin, who rapidly disseminated a much-transformed version of his scientistic approach. Whereas SaintSimon's earliest writings proposed a rationalist and technocratic reorganization of government, his followers instead built a religion of love and social harmony under Enfantin's leadership. Following his self-declared papacy, the école saint-simonienne skewed more and more toward the mystical, forming a sect in which sentiment increasingly replaced reason as a structural framework for both discourse and praxis such that the infamous rejection of traditional gender and sexual norms eventually led to multiple schisms within the group and ultimately to Enfantin's arrest in 1832. By this point, the group's so-called Parisian family, which included Vinçard, regularly organized liturgical spectacles and published propaganda aimed at bringing working-class masses into the fold.

As early as Lettres d'un habitant de Genève à ses contemporains (1803), Saint-Simon treated labor as foundational to his utopian reconfiguration of the French state. Drawing on a vocabulary that can be traced back to Abbé Sieyès's strategic revalorization of the third estate, Saint-Simon's social vision was built on the affirmation that "all mankind will work." ${ }^{36} \mathrm{He}$ actively promoted the image of a productive worker, or industriel in Saint-Simonian terms, as the privileged opposite of idle aristocrats, rentiers, and clergy. His tripartite system looked to harmonize relations among three different classes, industriels joined by savants and artistes, each of whom played a role in the successful functioning of a balanced society. In spite of its attention to labor, Saint-Simon's initial configuration was more hierarchical than egalitarian, and was not especially inclusive toward the working classes in and of themselves. However, by the late 1820 s and early 1830 s, the movement had shifted its focus and was actively seeking to grow the number of workers among its adherents. Saint-Simonian "missions" toured the capital's popular neighborhoods and established communal worker-run hostels on the rue Popincour and the Tour d'Auvergne, which sought to provide housing, education, and even medical care for the poorest classes. ${ }^{37}$ Special lectures and social services on the rue Taitbout were purposely held on Sunday afternoons allowing workers to come on their day off. Vinçard himself admits that some of the songs he wrote during those years were part of a larger work of propaganda aimed at the working-class clientele of singing clubs and drinking establishments. ${ }^{38}$ Despite these efforts to attract a mass audience, the Saint-Simonians' own records list only around 320 workers and artisans among their members in the early 1830 s. ${ }^{39}$ However, the cultural impact of these discourses on the writers I study here was nonetheless significant. As Roger Magraw points out, this same contrast between "productive" and "parasitic" 
classes was voiced in the very first issue of L'Artisan, suggesting that these discourses had indeed made inroads among the populations they targeted. ${ }^{40}$

The presence of Saint-Simonian concepts in working-class texts can be felt not just in their tendency to address laborers as society's most productive, and therefore, most valuable participants, but also extends to the social role they assigned to artistic practices. Saint-Simon's disciples regularly enlisted music, literature, and the visual arts as propaganda, believing that aesthetic expression could sway popular sentiment and promote social harmony. Thus, Emile Barrault's 1830 "Aux Artistes" preached the democratization of art, urging poets to "Sing, sing for everyone!" and calling on them to join a movement in which their work would be welcomed by an audience beyond the nation's elites:

Come, come to us all of those whose hearts know how to love [...] let us begin today to intone those saintly hymns that will be repeated by posterity; from now on, art is the cult and the artist is the priest. ${ }^{41}$

The image of the artist as priest is of course, as Paul Bénichou showed, one of Romanticism's most dominant themes, but it carried additional valence for the worker-poets and journalists I study here. ${ }^{42}$ Saint-Simonism facilitated the transcendence of distinctions between labor and literature by admitting both workers and writers into their reimagining of the platonic republic. As Rancière argues, "What worker poetry retained from Saint-Simonism is the more novel idea of the artist's social function as both the intellectual and manual laborer of the future, transcending current antinomies of work and pleasure [jouissance]." "43 At a time when the strict aestheticism of l'art pour l'art was gaining ground, Saint-Simonism did not just reinforce the social utility of creative practices, it also challenged assumptions about who could lay claim to the public expression of a socially relevant artistic vision. The writers I study here often drew on utopian socialist theories in their quest to redistribute the sensible, that is, to redraw the boundaries between what was visible and invisible, sayable and unsayable, legible and illegible.

While many of the writers to whom I refer in the following chapters including Vinçard, Lapointe, and Poncy had varying degrees of involvement with this movement, it is important to remember that SaintSimonism was only one out of a number of utopian approaches to the social question as it was posed in the 1830s and 1840s. Indeed, many early converts to Saint-Simonism soon grew wary of Enfantin's charismatic authoritarianism or were scandalized by his mystically grounded rejection of gender and sexual norms, causing schisms within the group out of which competing forms of socialism emerged. Fundamental figures include Pierre Leroux, whose brief involvement with the SaintSimonians in his role as director of their journalistic mouthpiece Le Globe came to an end around 1830. In the decades that followed, Leroux formulated a wealth of sociopolitical theories of his own. An autodidact 
who taught himself the printing trade, Leroux understood that the press was fundamental to the development and dissemination of socialism, a term he is credited with coining and disseminating. ${ }^{44}$ Leroux collaborated with George Sand on a number of journalistic ventures, including La Revue indépendante (1841-43) and La Revue sociale (1845-50), which he edited in printed with the help of the eighty-member utopian community he had founded in the town of Boussac. ${ }^{45}$ Although directed at a more socially elevated readership than the working-class newspapers I study here, La Revue indépendante was especially crucial during this period for its vocal defense of working-class writers. Articles penned by Sand herself like the "Dialogue Familier sur la poésie des prolétaires," which appeared in two parts over the course of 1842, placed working-class poets at the problematic center of socially-conscious Romanticism. ${ }^{46}$

Leroux's theoretical point of departure recalls Saint-Simonism since it also represents the social in terms of a balance between three terms, in his case composed of sensation, sentiment, and knowledge, all of which inhere in each individual and in humanity as a whole. "Through these three facets of his nature," Leroux asserts in De L'Humanité (1840) that "man relates to other men and with the world." 47 Leroux was in fact overwhelmingly focused on the question of relationality, and his theorizing of solidarity shows a careful calibration of the exigencies of both equality and difference that, Armelle Lebras-Chopard argues, differentiates it from other utopian theories at the time. ${ }^{48}$ As an antidote to capitalism's exaltation of individual interests as well as to traditional Christianity's definitions of charity, Leroux preaches the allegedly universal values of friendship and solidarity, understood as the productive relation between self and other, as the basis for the kinds of associative communities like the one he had created in Boussac and which he hoped would spread and transform relations of production. Through its emphasis on friendship, sentiment is central to Leroux's social theory as a fundamental mediational bridge between individuals. This emphasis on feeling also structures the unlikely sentimental plot at the heart of Sand's workerist novel, Le Compagnon du Tour de France (1841), as it does the best-known text penned by Agricol Perdiguier, the journeyman joiner whom she met in part through Leroux and on whom she based the protagonist of her novel. Perdiguier's Livre du Compagnonnage (1839) looked to rebuild the dismantled remnants of France's network of artisanal guilds into a training ground for association and collaboration. ${ }^{49}$ Perdiguier blended song and story into a book that was not just meant for journeymen like himself; he produced an oddly hybrid manual that unexpectedly captured the imagination of socialists including Leroux, Sand, and Sue. Here, as well as in texts he wrote before and after his tenure as an elected representative to the National Assembly from 1848 to 1852 , he exploits sentimentality to his own ends in ways that respond to and redress both Leroux's and Sand's concerns. 
Nineteenth-century utopian thought, including Saint-Simonism and Leroux's humanitarian socialism, tended to appeal to a self-selecting group of educated and articulate workmen. Like Vinçard and Perdiguier, they "became leading figures in radicalism, trade societies and other organisations, played key roles in running them, defining the terms of their debates, producing literature, resolutions, and toasts, and thus exerted an influence out of all proportion to their numbers." ${ }^{50}$ Yet for all of the similarities between Vinçard and Perdiguier - both were artisans making a living in Paris, both were skilled songwriters who made names for themselves as such, and both were drawn to socialist thought - the chapters that follow show how they each wrote as a way of reproducing their selves as distinct and unique as well as to bridge the gap between readers in their own and other classes. As Leroux claimed, "man uses culture to communicate with other beings who do not resemble him." 51 My analysis of the literature published by Vinçard, Perdiguier, and other working-class writers of their generation aims to show the rich diversity of the sphere in which they participated and which they sought to promote. The writers I study here were keenly aware that they were participating in a cultural field in which representations of working-class men and women were highly contested and where le populaire was a fraught concept whose nuanced meanings they sought to inflect and exploit.

The years during which these artisans were most active saw the rise of both Saint-Simonians and dissidents like Leroux, along with Charles Fourier, Étienne Cabet, and Pierre-Joseph Proudhon, all of whose social theories Marx later dismissed as "castles in the air." ${ }^{2}$ At the same time, a generation of Romantic writers were also swayed by this investment in what came to be known as the question sociale, with Hugo, Lamartine, Sand, and Sue taking the lead in socialist or workerist novels that openly claimed to speak for the working classes. The field in which Vinçard and Perdiguier tried to intervene was thus a crowded one, and the subsequent patronage of some of the same writers with whom they competed for an audience, including Sand and Sue, was doubled-edged. No doubt, working-class writers benefited from the support and exposure they got from spiritual (like the Saint-Simonians, Leroux, and others) and literary (like Sand) leaders alike. At the same time, they were accused from the outset of being mere puppets or apes of their socialist and Romantic betters. In Le Peuple (1846), Jules Michelet lamented that "recently, worker-poets have imitated Lamartine's rhymes [...] sacrificing what popular originality they might have had." ${ }^{53}$ Still today, critics and historians tend to read these texts as derivative imitations of "the love of nature, extravagance, idealisation, and floods of emotion of the Romantics." 54

These assessments nonetheless fall short. The workers I read here were cautious and thorough in their approaches to socialism and social Romanticism alike. They carefully negotiated social theories and literary positions, appropriating only those concepts and themes that might 
serve their needs and voices best. Nor were these writers unfiltered spokesmen for utopian thinkers. Lapointe's five-part poem, "L'Utopiste," which appeared in his first published collection of verse Une Voix d'en bas (1844), can serve as a succinct case in point. In this dialogue set in an Edenic valley between a weary and skeptical father and his eponymous son, socialist ideals are subjected to reasoned inquiry set to the steady march of alexandrines arranged in rhyming couplets. Framed as a lengthy dialogue between two workers of different generations, the Jacobin-like father, who harbors doubts about the possibility of an egalitarian future while mourning the demise of his own revolutionary ideals, questions his idealist son's measured optimism at every turn. While we can choose to read Lapointe's own discomfort with revolutionary action in the son's insistence on meditation and deliberation, the poem's dialogic form nonetheless remains suggestive of an active struggle to bring various voices and experiences to bear on social theories of the time. The son's eclectic socialism defies links to any one social movement or set of ideas: borrowing from Leroux's sentimentality and Saint-Simonian valorization of labor and Buchezian Catholicism, the poem ultimately counsels against accepting any one theory as true: "Often, a poor soul devoured by need/Waves a torch and says: behold the dawn!/And the wretched, from the edge of the horizon/Come running to our poker's dismal glimmer." In Lapointe's poetic estimation, it's the eponymous son who, in spite of his utopian leanings, warns readers against false prophets and promotes reasoned reflection as well as affective attachment over fruitless dreaming. ${ }^{55}$

Similarly, La Ruche populaire responded to critics who accused it of serving as a soapbox for Saint-Simonian theories by insisting that their collective editorial effort made the newspaper a forum for various voices instead of a vehicle for a single set of views: "Don't mistake the views of a few writers for the whole of our newspaper, which is and will always serve as an echo for all voices," they wrote, dismissing the idea that the social convictions of their editors like Vinçard were driving their opinions while adding that "If you have noticed that some among us are partisans of systems developed by Owen, Fourier, etc.... all this does is prove that we have searched everywhere for a better way, one that politics wasn't giving us at all." ${ }^{56}$ They explicitly urged their readers not to embrace ideologues and implicitly modeled ways in which new ideas could be subjected to rational examination and sentimental consideration alike. ${ }^{57}$ As such, the social discourses they embraced gave them a set of working terms that rendered their speech audible and discernable in a sphere which, in spite of its presumed openness, had traditionally been closed to minoritized voices.

Caught between the exigencies of the manual labor they performed in order to survive and the desire to resist their social and economic subordination as workers, these writers and poets were less invested in 
reproducing a fixed set of discourses and practices than they were in finding and redefining spaces within which reasoned public debate over political, social, and aesthetic ideas could take place. In addition to the cafés, singing societies, and other spaces of politicized social exchange that were traditionally open to workers like themselves, these writers also rose to the challenges posed by the demands of a newly mediatic society. If, as Rancière argues, the artisans drawn to Saint-Simonian and other kinds of socialism were less avant-garde radical militants than declassé artists, ${ }^{58}$ many of them nonetheless looked to the printed word in order to circulate both individual and collective demands for social and aesthetic reform.

\section{From public sphere to popular culture}

Poems like Lapointe's "De mon échoppe à Eugène Sue" and "L'Utopiste" are representative of a certain kind of social sentimental poetics which some, although not all, of the worker-poets I study here embraced. They are also exemplary of what many critics then and still today brand "bad" poetry. While my original aim in this book was to examine only the worker press as such, I found myself drawn to the poems these newspapers published and to their authors, whose status as lesser, minor or even just bad writers seemed uncontested. It is not my intention to integrate these poets into the nineteenth-century canon; indeed, the argument I advance here does not make claims about literary excellence, not least because, as Margaret Cohen reminds us, this very concept has been rightly problematized as ideological in debates over canon formation that date back to at least the 1980 s. ${ }^{59}$ I did, however, find myself questioning what it was about this particular literary archive that struck me as so powerful even as I had to admit that many of the texts within it seemed practically illegible beyond what they tell us as material artifacts about their immediate historical context. As I read through more and more of these poems, I was reminded of Louis-Sebastien Mercier's aphorism, which I included as the epigraph of the introduction and to its overriding point - namely, that assigning value to certain literary objects assumes and indeed depends on the devalorization of others. ${ }^{60}$ Indeed, part of what makes these writers so difficult to read as "literature" is that they embraced a poetics that, by the 1840 s, was already coming under intense critical pressure from aesthetic theories and practices that attained dominance over the course of the modern period and which can be traced at least in part to Kant's claims about pure judgments of taste.

Kant's exposition of what he calls pure taste emphasizes that objects can be considered beautiful only when they inspire disinterested pleasure in the viewer, and only when this pleasure derives from the contemplation of the object for its own sake. Distinguishing the beautiful from both the good and the agreeable, Kant famously set up the conditions for the emergence of modern aesthetics, under which art is consistently seen as a 
non-utilitarian activity that should ideally lend itself only to the detached appreciation of pure form and which, ultimately, reinforces broader assumptions about the similarity between the self and others. In fact, Kant defines taste in terms of the move from a subjective experience of pleasure to the universal expression of an intersubjective agreement about beauty. Thus, taste is "the faculty of estimating what makes our feeling in a given representation universally communicable without the mediation of a concept." 11 Indeed, Kant aligns taste with common human understanding, or what he calls a sensus communis, as "the idea of a communal sense" or "a faculty for judging that in its reflection takes account (a priori) of everyone else's way of representing in thought, in order as it were to hold its judgment up to human reason as a whole." ${ }^{62}$ What Pierre Bourdieu's critique of Kant's aesthetics asserts is that this move from subjective feeling to public invoking of "human reason as a whole" in fact conceals and represses the social origins of taste. For Bourdieu, judgments about taste are not pure and universal but instead grounded in an "empirical relation" that reinforces the opposition between the cultivated bourgeoisie and the vulgar popular classes. ${ }^{63}$ Likewise, in Terry Eagleton's terms, Kantian aesthetics is the "very paradigm of the ideological," as it reinforces the construction of the bourgeois subject. ${ }^{64}$

In 1840s, however, the Kantian aesthetics that we associate most readily with certain forms of Romanticism and l'art pour l'art was not the only one in play among cultural producers. Against this kind of aestheticism, social art as it was practiced by the writers I study here viewed artistic practice not as the reaffirmation of the uniqueness of the individual artist or spectator, but instead as the "sublimation of selfhood in the collective being of the polis." 65 Art could serve society by evoking moral good, as Sue's story about Pique-Vinaigre tries to show, by inspiring appropriate moral feelings in viewers and readers. Curiously both aestheticism and social art drew heavily on emotion, although to quite different ends as the editors of La Fraternité de 1845 made clear:

It seems that individual complaints do not influence public opinion, yet they are often the expression of deprivation experienced by all. From this point of view, we think it important to see something other than vague personal lamentations in the cries of pain uttered by literature's Renés, Werthers and Obermanns [...] the writers might have mistakenly thought that they owed their success to the richness and magic of their style, or to the more or less interesting novelistic form they gave to their works; they did not realize that they owed any glory they acquired to feelings expressed by the masses, of which they served merely as interpreters. ${ }^{66}$

While the Romanticism of Chateaubriand, Goethe, and Senancour aligned feeling with the uniqueness of the artistic personality, the writers I study here actively promoted sentiment and sensibility as keys to 